\title{
Teaching religions in Indonesian Islamic higher education: from Comparative Religion to Religious Studies
}

\author{
Media Zainul Bahri \\ Faculty of Theology State Islamic University Jakarta \\ E-mail:mediazain_75@yahoo.com
}

\begin{abstract}
This article focuses on how the study of Comparative Religion conducted in Indonesian Islamic higher institutions, i.e. on both UIN Yogyakarta and Jakarta since the beginning of the New Order (1960s) to Reform era (2014). The focus of the study was on models/approaches and main issues. In general, for more than half a century, the comparative study of religion is not been done for academic purposes an sich. Just within the new last decade that theoretical studies of Comparative Religion began developed. Another important thing that the study of Comparative Religion in Indonesia, although mostly referring to the methodological sources of the West and the Middle East, but it has always been associated with religious and cultural context of Indonesia. Therefore, the study on both UIN Yogyakarta and Jakarta always deliver courses on religions that live in Indonesia alongside with Indonesian contemporary issues. In the reform era, though still using Comparative Religion's term, but it looks religious studies such as used in the West. Thus, its "form" or "clothes" is Comparative Religion but it is religious studies.
\end{abstract}


Artikel ini fokus pada bagaimana studi Perbandingan Agama yang dilakukan di lembaga-lembaga pendidikan tinggi Islam Indonesia, yaitu pada UIN Yogyakarta dan Jakarta sejak awal Orde Baru (1960) Reformasi era (2014). Fokus penelitian adalah pada model/pendekatan dan isu-isu utama. Secara umum, selama lebih dari setengah abad, studi perbandingan agama tidak dilakukan untuk tujuan akademik an sich. Hanya dalam dekade terakhir studi teoritis Perbandingan Agama mulai dikembangkan. Hal lain yang penting bahwa studi Perbandingan Agama di Indonesia, meskipun sebagian besar mengacu pada sumber-sumber metodologi Barat dan Timur Tengah, tetapi selalu dikaitkan dengan konteks agama dan budaya Indonesia. Oleh karena itu, penelitian pada kedua UIN Yogyakarta dan Jakarta selalu memberikan kursus tentang agama yang hidup di Indonesia bersama dengan isu-isu kontemporer Indonesia. Dalam era reformasi, meskipun masih menggunakan istilah Perbandingan Agama, tetapi tampak sebagai religious studies seperti yang digunakan di Barat. Dengan demikian, "bentuk" atau "pakaian" nya adalah Perbandingan Agama bahkan religious studies.

Keywords: Comparative religion; Religious studies; Mukti Ali; Scientific-cumdoctrinaire; historio-chronological model

\section{Introduction}

This research focuses on models of Religious Studies (commonly called Comparative Religion) in Indonesia, from the early New Order period until the Reform era, concentrating on Islamic institutes of tertiary education. This research is important for reasons that are important as well. First, by knowing the genealogy of Comparative Study of Religion (CSR) and its development for nearly 50 years (1961-2014) at the Islamic colleges, it will be known a map of the discipline, which can be prepared to design the future development of an academic field. Second, the results of this study will show models of CSR born from struggle discourse and the idea of both Western and the Middle East CSR, then contextualized into the culture and Indonesian religious life. Therefore, this study will also indicate the CSR models are "unique" in compare to both the Western and the Middle East worlds. Third, looking at the contribution of CSR all 
the time, then in practice, the results of this study could be a reference in making strategic plans and regulations for the development of religious harmony, interfaith dialogue and cooperation among religions in Indonesia.

Some researches on the CSR that have been conducted are: Firstly, The Study of Comparative Religion by Indonesian Muslims: A Survey by Karel Steenbrink (1990). This article traces the CSR in the archipelago with a focus on Muslim leaders are considered to develop the study. Steenbrink starts with Nuruddin al-Raniri in the 17th century through his work, alTibyān fi Ma'rifat al-Adyān and the three members of the JIB (Jong Islamitten Bond) in pre independence: Mahmud Yunus, Zainal Arifin Abbas and HM Rasyidi. In the New Order era, Steenbrink unravels the role of Mukti Ali, Harun Nasution and Dawam Rahardjo in discussing Islam, comparative religion, and religious models of rational, progressive and functional. Secondly, A Pillar of Social Harmony: The Study of Comparative Religion in Contemporary Indonesia by Herman L. Beck (2002). This article focuses on the role and position of CSR -with Mukti Ali as the central figure-in the era before and during the New Order. Herman successfully outlines the significant role of Mukti Ali who pioneered the CSR in designing a model of interfaith dialogue in order to manage religious harmony and and pushed progressive religious thought that is in accordance with the spirit of New Order with its huge development projects. In this context, Herman also notes a strong relationship between the positions of CSR and the politics of the New Order, especially when Mukti Ali became Minister of Religious Affairs. Thirdly, an introductory article written by Ahmad Norma Permata of Metodologi Studi Agama (2000). Permata explains some Indonesian books related to the CSR in Indonesia, both written by Indonesian Muslim scholars and Western scholars who have translated into Indonesian. Permata also makes an interesting review of 
some of the character Indonesian CSR and its relationship with the International Association of History of Religion (IAHR) tradition that developed in Europe. Fourth, a research on Arah Metode Perbandingan Agama Di Indonesia: Kajian Bibliografis era 1980-an hingga 2012 by Singgih Basuki (2013). This research describes Indonesian books on CSR published over 30 years, both written by Indonesian Muslim scholars and Western scholars who have translated into Indonesian. Based on books published, Singgih analyze teaching methods of CSR. Fifth, a research on Pembelajaran Kontemporer Ilmu Perbandingan Agama di UIN Yogyakarta dan Jakarta Djam'annuri (2013). This research explains the curriculum, teaching, research and community services conducted by lecturers of CSR at the two universities. Sixth, a research on Analisis Elenktik Sebagai Model Pengembangan Ilmu Perbandingan Agama Pada Perguruan Tinggi Agama Islam by Ustadi Hamsah (2013). This research traces the History of CSR both in the West and in the Islamic world, the history of methodology of CSR, then offers a model the so-called "elenktik". This model is an subjective, in the sense of reviewing religions based on a "measurement" of certain religion (for instance, by official religion or majority religion) to explain it alongside with an approaches of Religious Studies such as sociology of religion, anthropology of religion, psychology of religion, phenomenology of religion etcetera.

A unique of my research is the analysis models of CSR on both UIN Yogyakarta and Jakarta (IAIN Semarang was used as a comparative research) produced more than half century based on teaching models, current issues in Religious Studies and Islamic Studies were included in the curriculum, and major references produced by Indonesian Muslim scholars who are focused on the study. Of course, comprehensive studies of CSR models are missed of researches and the articles above. 


\section{Study of Comparative Religion in the New Order Era: looking at the central role of Mukti Ali}

The CSR, among Indonesian Muslims, formally and academically born in PTAIN (Perguruan Tinggi Agama Islam Negeri) in Yogyakarta 1961. Exactly a year after the establishment of two state Islamic higher education, namely PTAIN Yogyakarta and ADIA (Akademi Dinas Ilmu Agama) Jakarta. The birth of the CR department at the Faculty of Islamic Theology can not be separated from the role of Professor Mukti Ali, a prominent Muslim scholar who earned his doctorate from the University of Karachi, Pakistan in the field of Islamic History, and got his Masters from McGill University of Canada in Islamic Studies. On 11 September 1971, Mukti Ali was sworn in as Minister of Religious Affairs (MoRA), in the cabinet of the New Order. Mukti Ali appropriately referred to as a Minister of Religious Affairs who occupies a special position in the history of Indonesian government policies in the field of religion, both in terms of its role in the long process of modernization of the religious-politics who is going through a "transition" period ${ }^{1}$ and in terms of his policies in regulating intra-and inter-relationship of different faiths, as well as its relationships (religious figures and institutions) with government. ${ }^{2}$ Because of his deep love for CSR-thanks to the strong influence of his professors Willfred Cantwell Smith-then when he became Minister of Religious Affairs, Mukti Ali was never tired introduced to students and the general public of the importance of learning the science of Comparative Religion (CR). He also makes the inter-religious dialogue as a key

\footnotetext{
${ }^{1}$ Ali Munhanif, "Prof. Dr. Mukti Ali, Modernisasi Politik-Keagamaan Orde Baru”, in Azyumardi Azra and Saiful Umam (eds) Menteri-Menteri Agama RI, Biografi Sosial-Politik, Jakarta: INIS, PPIM dan Litbang Agama Depag RI, 1998, 271.

${ }^{2}$ An interesting article discussing on how Mukti Ali designed the Comparative Religion subjects and its relationship to the New Order politics is A Pillar of Social Harmony: The Study of Comparative Religion in Contemporary Indonesia by Herman L. Beck (2002).
} 
policy in the Department of Religious Affairs. ${ }^{3}$

In his inaugural work on CR, Ilmu Perbandingan Agama (Sebuah Pembahasan Tentang Methodos dan Sistima, 1965 and 1969), Mukti Ali makes the following definition of Comparative Religion:

Comparative Religion is meant here that is a branch of science that aims to understand the symptoms of certain religious beliefs in relation to other religions. This understanding includes the similarities and differences. From the discussion of such, then the basic structure of religious experience of mankind and the importance of people's lives and livelihoods will be examined and evaluated. ${ }^{4}$

Ali's definition is similar to the definition written by Louis Jordan in his book Comparative Religion, Its Genesis and Growth (1905) which was deliberately referred by Ali. In his other work, Ilmu Perbandingan Agama Di Indonesia (1988), Ali again quoting the definition of Jordan, this time in full, that CR is "science that compares the origins, structures and characteristics of the various religions of the world, with the purpose to determine the factual similarities and differences, and the relationship between one religion and another religion”, Mukti Ali agreed. But when Jordan continued his statements: "to find the relatively superiority and inferiority among religions", Mukti Ali rejected it on the grounds that the superiority and inferiority among religions in the Western eyes is always measured with Darwin's theory of evolution. ${ }^{5}$ In pioneering this new science, Ali agreed that the three key words from the principal definition of the science of CR are (1) to find similarities and differences between religions, (2) to find the basic structure of the religious experience of mankind, and (3) the importance of religion in human life. Mukti

${ }^{3}$ Ali Munhanif, "Prof. Dr. Mukti Ali..., 283.

${ }^{4}$ Mukti Ali, Ilmu Perbandingan Agama: Sebuah Pembahasan Tentang Methodos dan Sistima, Yogyakarta: Yayasan Nida, 1969, 5.

${ }^{5}$ Mukti Ali, Ilmu Perbandingan Agama Di Indonesia, Bandung: Mizan, 1988, 14. 
Ali's definition, which dwells on the matter of connecting one religion with another religion and find similarities and differences in structure and religious institutions, seems to be an iconic standard definition since the 1960s until the mid-1990s, even today.

We can find these definitions in these following works: Perbandingan Agama by Moh. Rifai (1965 and 1980 [ $5^{\text {th }}$ ed.]); Pengantar Studi Perbandingan Agama (although recently published in 2005) by Thalhas, a senior lecturer of CR and disciples of Mukti Ali, who learned CR from 1958 to 1964; Diktat Perbandingan Agama by A. Halim Mastur (1970); Perbandingan Agama, Jilid 1 by Abu Ahmadi (1977); Yusuf Syuaib’s Agama-Agama Besar Di Dunia (1983); Menguak Misteri Ajaran Agama-Agama Besar by HM Arifin (1986); Perbandingan Agama, volume 1 and 2 (1983) book project, chaired by the Ministry of Religious Affairs, Zakiah Darajat; Agama-Agama Di Dunia (1988) a compilation book by lecturers of CR Yogyakarta, under the responsibility of Mukti Ali; Pengantar Perbandingan Agama by Kautsar Azhari Noer (1990, reprinted 2008), Studi Agama-Agama Dunia by Bahri Ghazali (1994); Ilmu Perbandingan Agama by Mudjahid Abdul Manaf (1994); Studi Agama, Suatu Pengantar (2011) by Syarif Hidayatullah etcetera.

From the definitions that have been referred may also be understood that the purpose of this study was tantamount to compare various different teachings and religious systems. Then, for what are religions being compared? Herein lays the problem. Mukti Ali himself in Ilmu Perbandingan Agama (1969) make a special chapter (Fasal VI) entitled "Guna dan Faedah Ilmu Perbandingan Agama bagi seorang Muslim [ benefit and avail of CSR for Muslim]." In that chapter, Ali underlined that the benefits of CSR for Muslims are to preach (show the superiority of Islam). ${ }^{6}$ Indeed, Islamic da'wah activities that are part of the CSR in the Mukti Ali statement are surprising because given that (1) he was one

\footnotetext{
${ }^{6}$ Mukti Ali, Ilmu Perbandingan Agama..., 38-40.
} 
of the favorite disciples of Wilfred Cantwell Smith, Grand Master of Comparative Religion at McGill, Canada whom he admired for the depth and objectivity as a scientist, and (2) he also criticized the views of Louis Jordan apologists "superiority and inferiority of religion", and (3) he has explained that this science is different from the science of propagation or da'wah, although CR was born in times tempestuous spirit of Islamic da'wah.

According to Djam'annuri, Professor of CSR UIN Yogyakarta, and second-generation disciples of Mukti Ali, in looking at of Mukti Ali's view about the relationship the science of $\mathrm{CR}$ with the perfection of Islam and its propagation purpose, one must look at the context. Namely, that the Mukti Ali pioneering CSR is not in public universities, but in Islamic universities. Therefore, the CSR must be seen as an activity of "studying non-Muslims religions as part of Islamic studies". Along with that, the impression of excellence or perfection of Islam is obtained by Muslim students when assessing CR/other religions is the effect of the study, not the goal of CSR itself. ${ }^{\text {? }}$

However, in the context of CSR to "demonstrate the superiority of a particular religion over other religions" and propagate to the "general public" is not acceptable. CSR, which is non-normative, can not compromise with the normative theology. Missionary zeal in the study of CR as stated Mukti Ali apparently passed on by many intellectual disciples of, who mostly have I mentioned above. They recognize CR as scientific research with scholarly approach was however fully agree with the missionary spirit of the canyon, that finality and the perfection of Islam compared to other religions and concerns if CR fully into scientific research and applied improperly it will siphoning faith.

\footnotetext{
${ }^{7}$ Interview with Djam'annuri, Yogyakarta February 26, 2014.
} 


\section{Methodology}

\section{Initial period: theological approach ${ }^{8}$}

In the sense of missionary zeal, we look at the early period of Mukti Ali as pioneering the science of CR describes the methodology to be employed. According to Ali, Comparative Religion is usually done from within the religion embraced by one in an attempt to evaluate the content and features of other religions. ${ }^{9}$ Again for $\mathrm{Ali}$, that knowledge of Comparative Religion can be a great danger for Islam, when mistakenly using it, but instead will be an enormous help in the development of Islam. ${ }^{10}$

From this point of view, it could be understand that the CSR makes an 'assessment' or 'judgment' of one particular religion over other religions. If we consistently follow this formula, the approach (method) in the CSR whether any phenomenological, historical, psychological, theological moreover, will always appear a "judgment" at the end or along within discussion. ${ }^{11}$ Mukti Ali himself when invited by the College of theologia Duta Wacana Yogyakarta (20 September 1968) to deliver a lecture on "the concept of One God in al-Qur'an" uses this method. The

\footnotetext{
${ }^{8}$ In an interview with Djam'annuri and Singgih Basuki, they do not agree there are two periodization in Mukti Ali thoughts. According to them, Mukti Ali has been consistent from the very beginning that the comparative study of religion in Indonesia is in the context of the Islamic institute, and it is a descriptive study with a scientific approaches. However, based on the comprehensive data of my research, I had to classified into two periods of Mukti Ali in which there is a period that he and his disciples emphasized aspects of apologetics, and there is a period-particularly in 1990s- where Mukti Ali was emphasized an objective aspects by designing scientific approaches, one of them namely scientific-cum-doctrinaire.

${ }^{9}$ Mukti Ali, Ilmu Perbandingan Agama..., 5.

${ }^{10}$ Mukti Ali, Ilmu Perbandingan Agama..., 39.

${ }^{11}$ Syarif Hidayatullah for instance, in his Studi Agama, Suatu Pengantar (2011) regretted if the science of Comparative Religion then used to assess and categorize other religions. In fact, the science of Comparative Religion that also means is the discipline of Religious Studies are trying to trace the similarities and differences and formulate the foundations and structures of various religions scientifically. See Syarif Hidayatullah, Studi Agama, Suatu Pengantar, Yogyakarta: Tiara Wacana, 2011, 18.
} 
IJIMS, Indonesian Journal of Islam and Muslim Societies, Volume 4, Number 2, December 2014: 155-188

lecture was later published as a book entitled Ke-Esaan Tuhan Dalam AlQur an (1969). At the end of the book, Ali confirms that in Islam there are not many sects that appear to contradict each other because the main sources, namely the Qur'an already clear and consistent about the concept of the oneness of God. It is different from Christianity. Mukti Ali "judged" that there are many clauses about the divinity in the Bible, thus, making it difficult to merge or synthesize because it is at odds with one another. ${ }^{12}$ Viewed from the perspective of current CSR, Mukti Ali's view is a theological perspective, not an explanation as a CR scholar.

Muslim scholars who wrote about the work of CR and have been stated above earlier such as Thalhas, Rifai, Mastur Halim, Abu Ahmadi, Zakiah Daradjat, Bahri Ghazali, Abdullah Ali, ${ }^{13}$ Agus Hakim, ${ }^{14}$ and many others are the "followers" or "disciples" of Mukti Ali in terms of the use of theological approaches. Other prominent figures using a similar method, but not a disciple of Mukti Ali, also appears such as Ahmad Shalabi, in which using theological approach in nearly all of his work on the CR and also Abu Zahra, Guest Professor in IAIN from Egypt, one of his works is Agama Kristen Menurut Pandangan Islam (1969).

Comparative approach in the spirit of theological apologetics, in the sense of comparing the superiority of Islam over other religions and beliefs began to emerge in the early 1960s and growing rapidly in the years afterward. Hasbullah Bakry for instance, wrote a number of books: Isa

${ }^{12}$ Mukti Ali, Ke-Esaan Tuhan Dalam Al-Qur'an, Jogyakarta: Jajasan Nida, 1969, 14-18.

${ }^{13}$ In his work, Agama Dalam Ilmu Perbandingan (2007), Abdullah Ali judge Judaism, Christianity and Buddhism through the eyes of Islam. Ali is the headmaster of Sociology at STAIN Cirebon and alumni of Comparative Religion from IAIN Jakarta in 1976.

${ }^{14}$ Agus Hakim's work entitled: Perbandingan Agama, Pandangan Islam Mengenai Kepercayaan Majusi, Shabiah, Yahudi, Kristen, Hindu, Buddha, Sikh, Semarang: Diponegoro, 2004, first time published in 1969, and reprinted in 1985, 2000, and 2004. From the title alone seems clear that the work is a "valuation" or "judgment" of Islam on other religions. Exactly the same thing is also done by Halim Masturi, Moh. Rifai, Abu Ahmadi, Abdullah Ali, and others. 
Dalam Al-Qur'an dan Muhammad Dalam Bible (1960), Yesus Kristus dalam Pandangan Islam dan Kristen (1965), and Al-Qur'an Sebagai Korektor terhadap Taurat dan Injil (1966). Also, Tharick Chehab who wrote Bible dan AlQur'an: Sebuah Studi Perbandingan (1961).

Again, Djam'annuri noted that any researcher on Mukti Ali should be aware that since the beginning of the establishment, Mukti Ali put CSR in the context of Islamic universities. That is, CSR should be understood as the activity of studying religions as part of Islamic studies. What is meant by Mukti Ali is that one day a Muslim scholar can understand the religions of non-Muslims, who have a sharp mind (well rounded) but still has maintained a commitment to Islam and piety. ${ }^{15}$ According to Singgih Basuki, a second-generation disciple of Mukti Ali, Mukti Ali's statement about "religious scientific" fits with the idea of Dr. Satiman and Dr. Mohammad Hatta (the proclamator) when formulating the Islamic University in the 1960s. Namely, that in the future, the Islamic Higher Education (PTAI) will produce scholars (experts) with intelligent mind but still maintained their piety. According to Singgih, this is consistently attached to personality of Mukti Ali until his death. ${ }^{16}$ With the testimony of these two close disciples of Mukti Ali, it is clearly illustrated that the Islamic "view" and its "measurement" are always inherent in the activities of CSR.

This is according to Burhanuddin Daya, CR Professor of UIN Yogyakarta and first-generation students of Mukti Ali, that until the early 1990s there has been no CR books written in Indonesian that meets the criteria of a purely objective, in the sense of fully accepted by followers of the religion which is the object studies. ${ }^{17}$ Daya also criticized some of CR

${ }^{15}$ Interview with Djamannuri, Yogyakarta February 26, 2014.

${ }^{16}$ Interview with Singgih Basuki, Yogyakarta February 25, 2014.

${ }^{17}$ Burhanuddin Daya, "Metode Penelitian dan Pengembangan Ilmu Perbandingan Agama.", Metode Penelitian dan Pengembangan Ilmu Pengetahuan Agama Islam Sympo- 
books circulating in the community. Many CR books in Islamic colleges and for senior high school students-during 1970s to mid 1980s-were written for the sake of da'wah. These studies usually do a comparison (rituals, creeds, prophets, scriptures of the religion compared to other religions). For Daya, comparative method is easy, but not always led to an objective view. ${ }^{18}$

Why Apologetics? According to Wilfred C. Smith, the discipline of Religious Studies (Comparative Religion) began to be studied seriously since the Age of Discovery when the Western Christian world discover other parts of the world and exploiting, find other religions and started investigating, thence gradually became aware of the existence of communities and regions that are far away from the their world and soil. ${ }^{19}$ In other words, there is a strong impression that CSR is the finding of the Western Christian, and the project initially, according to Ninian Smart, impressed the "Western imperialism and Christian superiority". ${ }^{20}$ Even in his particular explanation, Smith stated that the definitions and categories of "religion" are the finding of the Western Christian, which was then widely used and highly influential in the East. ${ }^{21}$ In the late 19th century until the mid-20th century, the Western Christian world itself can not deny that the CSR is taught in the seminaries was used to demonstrate

sium, Yogyakarta 14-16 March 1991, Balai Penelitian Pusat Penelitian dan Pengabdian Pada Masyarakat (P3M), IAIN Sunan Kalijaga Yogyakarta.

${ }^{18}$ Burhanuddin Daya, "Metode Penelitian dan Pengembangan Ilmu Perbandingan Agama”.

${ }^{19}$ Wilfred Cantwell Smith, "Comparative Religion: Wither-and Why", in Mircea Eliade and Joseph Kitagawa (eds) The History of Religions, Essays in Methodology, Chicago: The University of Chicago Press, 1959, 31-32.

${ }^{20}$ Zainal Abidin Bagir, "Strategi Pengelolaan Program Studi Perbandingan Agama di Indonesia, Tantangan dan Harapan.”, Restrukturisasi Program Studi Perbandingan Agama Symposium, Jakarta 26-27 November 2010, Faculty of Ushuluddin UIN Syarif Hidayatullah Jakarta.

${ }^{21}$ See Wilfred C. Smith, The Meaning and End of Religion, New York: Mentor Books, 1963. 
the superiority of Christianity over other religions which is encountered and discovered. Comparisons are made to put "other religion" in the frame subjectively, from their religious standard. This is what happens in a long period of CSR in the West.

Apparently, that's also the case in Indonesia. Is it a common phenomenon in many parts of the world. As is well known, in a very long time, theology was considered as Queen of the Sciences known to man. ${ }^{22}$ Therefore, it is not surprising that it has a very strong influence for centuries in collective memory of religious community. In Indonesia too, the theological mindset and attitude have a long history, both in the period before independence and in the days after independence until the collapse of the Old Order and New Order. Politically, as mentioned by Mukti Ali, da'wah spirit rise in Indonesia as a result of the communist insurgency in 1948 and 1965. The two events bring to the Muslims that the missionary spirit should be encouraged. ${ }^{23}$ In the heightened socio-political tensions between communism and religious people at that time, the socio-religious activities of any kind, including education, should be charged with da'wah.

Another point of emergence of apologetics attitudes and apologetics theological study is primarily theological polemics that occurred between Indonesian Muslims and Christians, which in its development involve many parties and the emergence of many publications theological works. ${ }^{24}$ Along with the above facts, Burhanuddin Daya also notes that in the very early, CSR is not well known, especially its methods. Moreover,

${ }^{22}$ See Hillary Rodrigues and John S. Harding, Introduction To The Study of Religion, New York: Routledge, 2009, 34.

${ }^{23}$ Mukti Ali, Ilmu Perbandingan Agama Di Indonesia..., 20.

${ }^{24}$ A quite representative and interesting explanation about it can be read in the work of Ismatu Ropi, Fragile Relation, Muslims and Christians in Modern Indonesia, Jakarta, Logos, 2000 . 
Muslim figures who involved in CSR are not graduate scholars. ${ }^{25}$

However, in the figure of Mukti Ali, we do not actually find him as an apologist, as in the description of other contemporaries Muslim scholars of his era. I already mentioned that, apart from admiring Wilfred Smith, Mukti Ali actually also have inherited the "way of thinking" of his mentor, but he had to be "careful" in dealing with Muslims euphoria over the new missionary zeal which taking place in that time. In January 1962 Mukti Ali delivered a lecture on Isra dan Mikraj, antara Iman dan Ilmu Pengetahuan. This lecture, in my opinion, provides a clear indication that Mukti Ali is a special Muslim scholar who does not like to apology. ${ }^{26}$

\section{Second period: pioneering scientific methodology}

In the spirit of rationalization and development of this science, then in the second period one may not be able to ignore the desire of Mukti Ali to make an assessment of CR became an autonomous science with a particular set of methodologies. He affirmed that CR is not an apology. It is not a tool to defend one's faith and religion, but on the other hand, Comparative Religion is a tool to understand the functions and features of religion, as a feature of the human instinct. ${ }^{27}$ For Ali it is possible for someone who has faith can believe something sympathetic towards other religions and beliefs. ${ }^{28}$

\footnotetext{
${ }^{25}$ Burhanuddin Daya, "Kuliah Ilmu Perbandingan Agama Pada Institut Agama Islam Negeri (IAIN)", in Burhanuddin Daya \& Herman Leonard Beck (eds) Ilmu Perbandingan Agama Di Indonesia dan Belanda, Jakarta: INIS, 1992: 185-186.

${ }^{26}$ Mukti Ali, Bagaimana Menghampiri Isra' Mi'radj Nabi Besar Muhammad SAW atau Iman dan Ilmu Pengetahuan, Jogjakarta: Jajasan Nida, 1969, 20-22. The lecture was delivered in 1962 but published as a book in 1969. In the lecture Ali critized the apology. For him, Muslim apologists are "blindly" defending Islam from the attacks by showing that the perfection and excellence of Islam are the whole goal, ideas, values and its implementation perfectly.

${ }^{27}$ Mukti Ali, Ilmu Perbandingan Agama..., 7.

${ }^{28}$ Mukti Ali, Ilmu Perbandingan Agama..., 7.
} 
Two important statements that CSR is not "theological apologetic attitude" and the ability or necessity of a scholar of CR to be "sympathetic" to the beliefs of others, shows that since the beginning of Mukti Ali was aware of the necessity for the independence of this science, and CR has a clear distinction with Theology, History of Religion, and Philosophy of Religion. Mukti Ali mentioned the existence of three principal parts of Science of Religion namely: History of Religion, Comparison of Religion, and Philosophy of Religion. This division in perspective Mukti Ali showed that CR is an autonomous discipline. ${ }^{29}$ For Mukti Ali, in that period, "Comparison" is a scientific discipline, which has different approaches (definitions, objectives and methods) with the branches of other religious sciences.

In his work in the second period which is also an introduction at the Peringatan Seperempat Abad Ilmu Perbandingan Agama seminar at IAIN (a work that leads to the archway of Mukti Ali's retirement in August 1988) entitled Ilmu Perbandingan Agama Di Indonesia (1988) aspects of the scientific method of CSR look more prominent. In short, Ali agrees that social science approaches can be used in CSR but he reminds-by quoting Mircea Eliade- that the meaning of a religious phenomenon can be understood only if it is studied as something that religious. In addition to social sciences, there must be a way to be able to capture a phenomenon that was born from the the Holy. ${ }^{30}$ By means of a mixture between the dogmatic and social sciences Ali has made a new "synthesis" approach the so-called "religion-scientific" or "scientific-cum-doctrinaire" or "religious scientific". 31

How can subjective religious experience be investigating? For Mukti Ali, what is subjective could be objectified, because it has a variety of

\footnotetext{
${ }^{29}$ Mukti Ali, Ilmu Perbandingan Agama..., 6-7.

${ }^{30}$ Mukti Ali, Ilmu Perbandingan Agama..., 70.

${ }^{31}$ Mukti Ali, Ilmu Perbandingan Agama..., 79.
} 
expressions, and those expressions have a positive structure that can be learned. Religious experience is expressed in three forms: first, theoretical or intellectuals, including theology, cosmology, and anthropology; second, practical, namely worship; and third is sociological, the expression in the form of social interaction. ${ }^{32}$

Mukti Ali has made such a map the quite systematic, simple, and can be applied comprehensively, in the sense that those social sciences can be used as a methodological device. Regardless of the fact that in general the dominant pattern which is still visible is in the theological aspects (or approach). However, at that time Mukti Ali has started to introduce the social sciences in the study of religion. ${ }^{33}$ In this period, it can be said that Mukti Ali has anchored the methodological aspects for CSR. Even in the two periodization that I made, which is in the range of nearly three decades (1961-1988), his career and dedication in this CSR has made it as discipline and method (comparison) until transformed into a clear entity, at that time, be in the ontological, epistemological and axiological aspects as typically an autonomous science. This is the greatest merit of Mukti Ali in establishing the science of CR in Indonesia as a really new science in the constellation of religious studies of Indonesian Islam. Because of that, he known as the father of Indonesian CSR. ${ }^{34}$ Although it

\footnotetext{
${ }^{32}$ Mukti Ali, Ilmu Perbandingan Agama Di Indonesia..., 79-80.

${ }^{33}$ Moeslim Abdurrahman in an article about Gus Dur and Cak Nur recalled that Mukti Ali was "the first generation (along with Rasyidi and Harun Nasution) Indonesian Muslim intellectual who introduced the social sciences to young Muslim intellectuals to lecture on Comparative Religion and the issue about the methodology of religious study". See Moeslim Abdurrahman, "Dua Pendekar", in Sukandi (ed) Tharikat Nurcholishy, Yogyakarta: Pustaka Pelajar, 2001, 60. Regardless of the recognition of many Indonesian Muslim intellectual, Mukti Ali himself in his work did show that he pioneered the social science approach to the study of Comparative Religion.

${ }^{34}$ About this title, the students of Mukti Ali and researchers of Comparative Religion afterwards never argue. They agreed on the contributions and pioneering of Mukti Ali in this discipline in Indonesia. A special writing about this was writen by HA Ludjito entitled "Bapak Ilmu Perbandingan agama di Indonesia", in Herman Leonard Beck dkk (ed) Ilmu
} 
must keep in mind that all of Mukti Ali's efforts in affirming the CSR on the aspects of terminology, methodology and axiology is in the context of Islamic Universities.

Some senior "disciple" of Mukti Ali in the early 1990s later on reinforces the methodological aspects and ways of working in these disciplines. Just to name a few examples such as Burhanuddin Daya, Alef Theria Wasim, Amin Abdullah, Romdhon, Djam'annuri, and Singgih Basuki of UIN Yogyakarta, Farihin Chumaidi of UIN Bandung, Kautsar Azhari Noer of UIN Jakarta is CR expert scholars who contribute to the clarification of the object, scope, and the workings of CR. In turn, they continue to drive the science of CR towards the new transformation, both methodological aspects and issues that continue to grow.

Period of transformation that is critical to the development of CSR is in the era of the 1990s. This is the time of fresh air for CSR, both in terms of methodology and the issues arose in the religious discourse (including the Islamic studies). CSR program itself in many IAIN, bustling demand by prospective students and enthusiastically appreciated by various community, especially activists and practitioners of religious studies and interfaith forums. Appreciation and enthusiasm for the current CR studies may be viewed in two important respects: first, in this era, in the

Perbandingan Agama di Indonesia (Beberapa Permasalahan), Jakarta: INIS, 1990, 13-17. Also, Burhanuddin Daya's work entitled "Kuliah Ilmu Perbandingan Agama Pada Institut Agama Islam Negeri (IAIN)". In that work Berhanuddin Daya stated, "One hundred years after Max Müller was born in Germany, in Cepu, Central Java, also born Mukti Ali (1923). Whether this can be attributed to "God Sent a pioneer every hundred years", I do not know for sure. Which is the real world of science can not deny the important role of A. Mukti Ali in the matter of Comparative Religion in Indonesia. See Burhanuddin Daya, "Kuliah Ilmu Perbandingan Agama Pada Institut Agama Islam Negeri (IAIN)", in Burhanuddin Daya \& Herman Leonard Beck (eds) Ilmu Perbandingan Agama Di Indonesia dan Belanda, Jakarta: INIS, 1992, 182. However, in his 70 Tahun Mukti Ali, Agama dan Masyarakat biography, Mukti Ali himself humbly rejects mention himself as "Father of Comparative Religion in Indonesia”. See Abdurrahman (ed) et.al, 70 Tahun H.A.Mukti Ali, Agama dan Masyarakat, Yogyakarta: IAIN Sunan Kalijaga Press, 1993. 30. 
Western (Universities) world, research on religious studies experienced a significant leap forward, it transform beyond the approach of Theological and Religious History. This is in line with the religious enthusiasm of Western society because of the failure of modernism in bringing spiritual warmth and makes a man alienated from the life and themselves. At the same time, many lecturers from the IAIN who sent to study abroad, especially Western countries, as one of the flagship program of the Department of Religion at that time (which was initiated by the Minister of Religion, Munawwir Syadzali) began to return to their homeland and bring "gifts" in a form of new religious studies issues and its methodological. This situation directly affects the emergence of new forms of religious studies in Indonesia that is progressive, even "controversial".

Second, situation in the 1990s is the twilight of the New Order. Wave of democratization ala the developed countries cannot be dammed to enter Indonesia. The discourse of democracy to bloom at that time is a question of politics, leadership succession, and the social order. It inevitably has to discuss the role of religion: concerning the public understanding of religion, religious institutions, how to manage religious pluralism in a democratic state, the position and contribution of religious interpretation to the hot and new issues. Apparently, the encounter of first factor with the second that causes CSR received widespread attention and is, for example, in line with the expectations of society for the contribution of CSR in the field of religious harmony for the socio-religious life that was sliding toward a dramatic change.

Several issues are important in this era: religious harmony, religious pluralism, passing over and interfaith dialogue, all of them significant enough to influence the development of CSR and Islamic studies along with the accompanying methodologies. 


\section{Historio-chronological model}

One of the prominent models of teaching CR is a historio-chronological approach. It lasted from the beginning of CR' Department established until the end of the New Order, even until the time of Reformation. Religions are introduced to students from the beginning of its history to its development. This model is seen explicitly in the works of CR since the time of Mahmud Yunus' work al-Adyān to Agama-Agama Besar Masa Kini by Sufa'at Mansur (2011).

After parsing the history of a religion, either in detail or summary, the works will then make the specific discussion: about God, Messenger, Scripture, Ethics, Law, Eschatology and sects that emerged later. With such a model, there is an impression that the author and the instructor of CR make 'boxes' which caused everyone involved in the process of reading and understanding the religions of non-Muslims were still seen as 'outsiders'. Therefore, it is difficult for students and teachers into the figure of 'insiders' that shared in and appreciate the religious meaning as perceived by its adherents. With such a model, though not entirely socalled "failed" to understand the religion of other people who are not their religion, but it would be hard to find the inner meaning of religion that examined. In fact, it's where the main goal to study the religions of man.

Historical-chronological teaching model that is "stiff and dry" also made a model that generally is held in the Islamic world-in teaching Islamincluding in Indonesia. Historical models that are not accompanied by a critical attitude, in which the dogmas taught doctrinal, make Muslim students fail to understand the deepest meaning of Islam that shows God's love and the grandeur of humanity.

One of the best CR models of teaching, in the sense of how to understand the religions of the non-religious through sympathetic understand- 
ing and deep, is the model of Huston Smith through his work The Religions of Man (1975) that was later revised as The World's Religions: Our Great Wisdom Traditions (1991). Smith's book is a philosophical work on the inner conviction and world view of those who profess the religion of sorts; an in-depth and startling description even to the "inner people" or its own adherents. Smith did not explain a religion based on the chronology of its history and concepts that will give the impression of being a series of 'boxes' worldview and religious beliefs. However, it presents a psychological experience of religious people, a collection of inner rich experience, and their vastness horizons.

With in-depth descriptive models, Smith showed some important things in the Study of Religions, which are: first, Religious Studies are the study of human beings, or rather about concrete human experience of diversity and divinity. Smith put religion not as data, facts and events that are dead and frozen, that only contain records of events, occurrences, and mere names. Therefore, Smith in his study did not include many of person's name, place, or event. Smith emphasizes that the history of religion is the history of the lives of their followers who are living, dynamic, and ever-changing. ${ }^{35}$ That's why his book was entitled Religions of Man. Second, Smith's book presents a direct experience of religious adherents. As if we are invited in person, hearing the narrative of its own followers. We also got the impression that he had become a 'spokesperson' or 'insider' of the religion that is being explained.

Third, Smith shows how the teaching of the great religions, which is concrete, was indeed also become the attention of 'another world', namely the scientists and philosophers. Smith always connects religious teachings with the views of the philosophers and scientists of the world; an

\footnotetext{
${ }^{35}$ Ahmad Norma Permata, "Pendahuluan Editor"..., 30.
} 
interesting and surprising connection. Fourth, Smith performs complex discussion about the themes connected or analyzed with other themes simultaneously. When talking about the man in Hinduism, for example, Smith also relates to the concept of God and the doctrine of mukti: The ultimate goal of Hinduism. After the sub-heading "What People Want", Smith made other sub-headings subsequently: "The Beyond Within", "Four Paths to Goal”, "The Way to God through Knowledge", "The Way to God through Love", "The Way to God through Work", "The Way to God through Psychophysical Excercises", "The Stages of Life", "The Stations of Life", "Thou Before whom All Words Recoil", "Coming of age in the Universe", "The World,Welcome and Farewell", and finally "Many Paths to the Same Summit". Once again, we did not find a specific subtitle of "God concept" for example nor "Scripture", "History of Hinduism", "Law and Hindu Rites", nor the doctrine of "sages" as messengers of God in Hinduism. However, with sub-headings which he made above, Smith has succeeded admirably describes the basic teachings of Hinduism about God, scriptures, rituals, concepts of human, Hindu mystics, and many others without making the 'box themes' of those topics.

Meanwhile, the course of the CR models are usually conducted in Indonesian is-apart from a generic way such as lectures, discussions and presentations of papers-it is most preferred by students and lecturers are visiting places of worship of non-Islamic adherents or their religious studies centers to observe their ritual practices, or discuss and listen directly about what the beliefs and their religious worldview. Visiting places of worship and religious studies center is a moment for students and faculty to deal with other religious traditions as a fact of life in the community. It is not merely opening their intellectual horizons, but also provides the richness of inner and emotional touch on other different traditions. Model of comparative excursion seems to have been a part of the teaching of 
theology in Christian's seminaries, Hindus and Buddhists in Asia. ${ }^{36}$

Overall, the model studies conducted since the beginning of the establishement of CSR Department up to the end of the New Order can be divided in two periods: First, the model of normative period (from 1961 to mid-1980), which studied the religions of non-Muslims by using a number of approaches, though in the end will be pulled on theological approach (subjective). It is obvious the existence of a dominant model, namely a model of historical-comparative-theological, or historical-theological plus phenomenological, or comparison-theological. Religions of man are seen based on the historical, theological doctrines, and religious phenomena that surround it, and then compared to Islam or 'valued' by Islam. Second, the era of the non-normative or descriptive model (from late 1980 to late 1990), this model strives to be more scientific. This model saw religion or religiosity of a community with more aspects of complex study, and is subject to the rules and regulations that occur in scientific disciplines and approaches. However, it should be understood too that the above two periodization, normative and non-normative, overall is not 'absolute'. Very likely there are flexible conditions in every period. Perhaps, there are a number of works with 'semi-scientific' patterned in the era of normative, or that there has been some work with 'theological-apologetic' pattern in an era of non-normative as the works we have seen in that two periode.

Throughout this era, we see CSR is done by following the tradition of Western scholarship (including the Western Christian) which contextualized with the socio-religio reality of Indonesian society. Those two patterns are particularly noticeable in the prominent figure of Mukti

${ }^{36}$ Regarding these activities in Asia see Ihromi, "Mengkaji Agama-Agama Yang Masih Hidup Dalam Sebuah Masyarakat", in Burhanuddin Daya (ed) Ilmu Perbandingan Agama Di Indonesia dan Belanda..., 178. 
Ali. Intellectual disciples and his followers dispersed, especially in Java, a 'funnel voice' of Mukti Ali-especially in the Department of Comparative Religion at IAIN, which of course by inserting several variations and further developments of what has been formulated by him. In this case Mukti Ali made a large contribution in taking an abundance of Western references and processes it for pluralistic Indonesia and in the context of its Islamic universities. Therefore, the pattern of CSR in the New Order is not merely Western oriented, both in terms of content and methodology, but also involves its Indonesianess context. It can be viewed on the syllabus of the class, which discusses living religions and beliefs of Indonesia, one of them is Javanese Mysticism.

However, the result of my research was in line with the Ahmad Norma Permata notes. He underlined three important character models of religious studies in Indonesia, especially in the early days of its appearance. First, the study of religions (not religious studies) in Indonesia built according to the principles of Religionwissenschaft tradition and IAHR (International Association for the History of Religions). The main character of this tradition is the will to make the study of religion as a discipline which is independent, objective and scientific, but still has a religious nuance. Scientific-cum-doctrinair ala Mukti Ali reinforces that view. ${ }^{37}$

Second, religious studies in Indonesia were originally developed only in institutions that have a formal affiliation with a particular religion, which incidentally has a religious mission (da'wah). In the case of Indonesian Islam, Comparative Religion officially opened the first time in PTAIN Yogyakarta and followed by ADIA in Jakarta is not organizing in the light of Religionwissenschaft. ${ }^{38}$

${ }^{37}$ Ahmad Norma Permata, "Pendahuluan Editor", in Ahmad Norma Permata (ed) Metodologi Studi Agama..., 41.

${ }^{38}$ Ahmad Norma Permata, "Pendahuluan Editor"..., 42. 
Third, religious studies in Indonesia also have a strong tendency toward pragmatic activism of the religious community at large. A study of the phenomenon of religion has never been done solely for the sake of scientific or academic world an sich. It happened mainly because the practitioners of religious studies mostly active in the religious institutions. ${ }^{39}$ Mukti Ali himself had regarded as a special scholar from Western upbringing still stick to the traditional Muslim view that activity in life is to worship. Again, at this level we can see Mukti Ali as a Muslim theologian who directs CSR for religious purposes and practical. ${ }^{40}$

\section{From Comparative Religion to Religious Studies}

At the time of the Reformation (2000-2014), name of "Comparative Religion" is still used in many IAIN and UIN, especially in both UIN Yogyakarta and Jakarta. Actually, at the time of the Reformation, among young lecturers at UIN Yogyakarta and Jakarta such as Ahmad Muttaqin, Ismatu Ropi and Dadi Darmadi have a strong desire to change the name of this CR department into religious studies. According to Muttaqin, the name of CR in this open democracy is too 'sensitive'. At a time when religious fundamentalism strengthened, the term Comparative Religion has always been a target from Islamists who consider courses that 'dangerous'. ${ }^{41}$ The other major reason according Muttaqin is that the science of CR in the New Order did not have an established epistemology yet.

${ }^{39}$ Ahmad Norma Permata, "Pendahuluan Editor"..., 43-44.

${ }^{40}$ In this context, view of B.J. Boland about the work of Mukti Ali, Ilmu Perbandingan Agama: Sebuah Pembahasan Tentang Methodos dan Sistima (1965) is right that this work is not really a work of Comparative Religion, but rather works on the theology of religions. See B. J. Boland, The Struggle of Islam In Indonesia, Leiden: KITLV, 1982, 211.

${ }^{41}$ Interview with Ahmad Muttaqin, Yogyakarta February 25, 2014. Muttaqin earned his Ph.D in the Center for the Study of Muslim Society, University of Western Sydney, Australia (2012). Recently, he is Head of Comparative Religion Department at UIN Yogyakarta. 
At that time, CSR leads to more activism than academic activities. While at this time, the science of CR has been growing rapidly, both in terms of methodological aspects and of the materials. ${ }^{42}$

Ismatu Ropi, younger generation lecturer of Comparative Religion UIN Jakarta, has a critical perspective regarding 'the world of comparative religion' and 'the world of religious studies'. According to him, in comparative religion, the elements of a particular religion-like in theological studies-compared with other religious elements. However, it is often the case, the comparison is done from the point of view of "a great religion", or from the perspective of "a particular religion" when looking at other religions. This perspective is once has a long predominate in the study of comparative religion in the Western Christian world. This model is more prescriptive, in the sense; there must be certain elements as a 'tool' to measure other religions. ${ }^{43}$ Indonesian Islamic universities-from its beginning to this day-stuck using these prescriptive models. Perspective to measure even to judge other people's beliefs are usually the hallmark of comparative religion. The 'worst' thing finally happened is the desire to show superiority of particular religion over other religions. ${ }^{44}$

Conversely, according to Ismet, his nickname, if on comparative religion prescriptive studies is more emphasized, then the main character of religious studies is descriptive, in the sense of how the religious elements described as meaningful for its adherents. The descriptive is usually interpreted as "an explanation of the phenomenon that can be measured". In fact, in religious studies, what desired in a descriptive study is an explana-

\footnotetext{
42 Interview with Ahmad Muttaqin, Yogyakarta February 25, 2014.

${ }^{43}$ Interview with Ismatu Ropi, Jakarta May 12, 2014. Ismatu Ropi holds Ph.D in the Department of Southeast Asian Studies, ANU, Australia (2013).

${ }^{44}$ Although eventually it is not always end up just like that. Interview with Ismatu Ropi, Jakarta May 12, 2014.

${ }^{45}$ Interview with Ismatu Ropi, Jakarta May 12, 2014.
} 
tion of the meaning (noumena), in addition to that phenomena. ${ }^{45}$

With the above explanation, Ismet as if want to assert that the most ideal model for the Study of Religions is religious studies. In addition to the criteria of 'objective or 'scientific', this model is also humanist. If one want to talk strictly about religious studies, the term of comparative religion models with its some negative excesses are indeed untenable. Even the name "Comparative Religion"-with its more pejorative tone-actually cannot be used again.

However, most of the older generation does not agree the change of name. According to Djam'annuri, the objection of the change of name, including himself, has at least three main reasons: first, historical reasons. The name of Comparative Religion has a long history in the West, the Middle East and in Indonesia itself. Second, academic reasons, the name of Comparative Religion are still used in many universities around the world. Third, the core of Comparative Religion is fixed in position, namely studying religions other than their own religion. The fact is that the program is still running on the department of CSR, at least in two great UIN, the UIN Yogyakarta and Jakarta. ${ }^{46}$

In line with Djam'annuri, Kautsar Azhari Noer, Professor of CR UIN Jakarta considers that the names of Comparative Religion still relevant to be maintained. Kautsar convinces that the core study of CR is a theological doctrines and religious practices, even beyond, which are the thoughts and spiritual experiences. This is the spirit of religions. Kautsar pointed to one example in the book entitled Encyclopedia of Spirituality, Essential Teachings to Transform Your Life (2000) containing a comparative study of the mystical aspects of religion as an ideal model of the core studies of CR. Similarly, the book by Toshihiko Izutsu, Sufism and Taoism

\footnotetext{
${ }^{46}$ Interview with Djam'annuri, Yogyakarta February 26, 2014.

${ }^{47}$ Interview with Kautsar Azhari Noer, Jakarta May 19, 2014.
} 
(1984), according to Kautsar is one of the best books on CR. ${ }^{47}$

Kautsar can actually understand the area of study in religious studies and its approaches that developed over the years. However, he saw religious approaches to these studies more focused on the social sciences. In which, in the context of its materials and approaches of the science of $\mathrm{CR}$, it will overlap with the disciplines of the social sciences. Therefore, Kautsar does not agree if the pressure point approach to the social sciences is part of the core of CR. According to him, if a study is its emphasis on the social sciences approach, though the object of religion, then it is more suitable in social science courses, not in CR. ${ }^{48}$

According to Kautsar, criticism on the CR name and aspirations to change of its name to 'religious studies', in fact, is based on the primary factors, namely that up to this time the works of academics of CR tend to be un-objective, shallow, less on perspectives, inappropriate and unfair comparison, and mostly within a patterned of theological-apologetic. There is no work of the CR in Indonesia, which is 'great' as World's Religions of Huston Smith; The Transcendent Unity of Religions of Schuon; The Pattern in Comparative Religion and The Sacred and the Profane of Mircea Eliade; What Is Scripture? and The Meaning and End of Religion of Wilfred C. Smith; Hindu and Muslim Mysticism of Zaehner; Symbol and Symbolism of Martin Lings; Sufism and Taoism of Izutsu; Three Faiths One God: A Jewish, Christian, Muslim Encountering of John Hick and Edmund Meltzer (eds.); Encountering God: A Spiritual Journey from Bozeman to Banaras of Diana Eck and others. According to Kautsar, knowledge is attractive if it is written in a way that is interesting. Those works of Western scholars are indeed the work of CR, with an emphasis on 'thoughts and spirituality', in which using a lot of other disciplins perspectives such as history,

${ }^{48}$ Interview with Kautsar Azhari Noer, Jakarta May 19, 2014. 
sociology, anthropology, psychology and hermeneutics. However, Kautsar admitted that compared to time of the New Order era, the works of CR scholars in the era of Reformation has been more objective, fairer and more profound comparison although no one has 'equivalent' quality to the works of Western scholars. ${ }^{49}$

Dadi Darmadi, a young lecturer of CR at UIN Jakarta concentrating on anthropological studies, does not agree to Kautsar in the case that the study of sociology and anthropology is not part of CSR core. According to Dadi, those two social science disciplines are a legitimate and important part of the CSR. Dadi refers to classic Joachim Wach, The Comparative Study of Religions (1958), which became a favorite reference book of Mukti Ali and is still used in the CSR program. In the book, Wach explained that the expression of religious experience takes three principal forms, namely in thought, deed, and communion (fellowship). Thus, in the form of communion character, association or organization, then the approach is through the social sciences. ${ }^{50}$ Wach itself confirms that the expression in the form of fellowship is not an extra from the other two, the thoughts and actions. Those three aspects are equally essential. ${ }^{51}$

Consequently, regardless of the fact there is a polemic between the old and the young people in the case of changing the name, the name of Comparative Religion is still applied as the name of the department/ program of study that is valid to this day. By the name of the CSR, the department continues some old traditions that are considered still relevant and add new things that are considered actual and contextual. For example, courses on religions are still taught separately, as well as courses

\footnotetext{
${ }^{49}$ Interview with Kautsar Azhari Noer, Jakarta May 19, 2014.

${ }^{50}$ Interview with Dadi Darmadi, Jakarta, June 5, 2014. Dadi Darmadi is a Ph.D candidate in the Department of Anthropology, Harvard University, USA. He holds an MA in Religious Studies at Colorado University, USA (1998).

${ }^{51}$ Joachim Wach, The Comparative Study of Religions..., 121.
} 
of Religious Studies methodology are still maintained. In addition to the conventional, both UIN Yogyakarta and Jakarta create new subjects in accordance with the demands of the scientific and religious life. In general, the subjects were under the umbrella of "Religion and Contemporary Issues". UIN Jakarta, for example, has opened a new course subjects such as Religious Fundamentalism, Religion and Science, Themes of Comparative Religion, Methods of Study of Religions, Gender Relations in Religions, State Regulation on Religion, Local Religions, Orientalist Studies of the Qur'an and the Hadith, and the New Religious Movements. UIN also made the courses of Indonesianness subjects, such as Islam in Indonesia, Christians in Indonesia, Hindus and Buddhists in Indonesia, and Confucianism in Indonesia.

In addition to designing contemporary issues as did UIN Jakarta, what is interesting from Yogyakarta's CR is strengthening "the hallmark of Islam" for CSR in the past by creating two new courses, namely the Science of Comparative Religion in the West (CR I) which discusses CSR developments in the West and the Science of Comparative Religion in the Muslim World (CR II). For CR II's subject, Djam'annuri named with reference to ICSR: Islamic Comparative Study of Religion. Core topics in ICSR are a model of CSR in Abd al-Karim Shahrastani, al-Biruni, Ibn Hazm, Mukti Ali, and studies on religions of the modern Muslim scholars. Then, there is material on Contemporary Islamic Relations with Other Religions (Theological and Historical Relation). ${ }^{52}$ Reinforcement for Islamic materials and ICSR is presumably created to continue the spirit of Mukti Ali CSR; a model that was developed to fit the context of Islamic universities.

If looking at the response and rapid adaptation from both the CR study program on the grand theme of Religion and Contemporary Is-

\footnotetext{
${ }^{52}$ Interview with Djam'annuri, Yogyakarta February 26, 2014. See also Course Syllabus of Comparative Religion UIN Sunan Kalijaga Yogyakarta 2006, vii.
} 
sues, the CSR had actually come up with new "content" or "body", nevertheless, it is still in the old "pack", "face" or "clothes". CSR has led to the current model of Religious Studies as practiced in the West, despite the fact not yet at the maximum stages. The name of "Comparative Religion" also has limited the study area. If there are lecturers who are experts in political science approach, mass media or pop culture, it would appear the impression of overlap with other courses, such as courses in political science, social science and communication science. However, the problem of religion and contemporary issues in fact has received serious attention among CR scholars. Since the beginning of the Reformation era, it has been a realization that if the Comparative Study in the New Order era seemed to have become "disciplines" but now Comparative model is just one of these numerous approaches in Religious Studies.

In comparison to both models' UIN Yogyakarta and Jakarta, what is interesting in the models of "old shirts on a new body" is what's going on in the CSR program of IAIN Wali Songo Semarang. Comparative Study of Religion program was opened in Semarang in 1998, exactly at the transition from the New Order to the Reformation era, as transferred courses from STAIN Kudus. According to Nasihun Amin, Chairman of the Department of the CR 2002-2006 (previously Dean of the Faculty of Islamic Theology 2010-2014), of the 2004 to 2008 CSR programs are part of the Islamic Theology which in addition to mastering the aspects of Islamic theology, also mastering the aspects of history and religious teachings. Therefore, the curriculum made for skill courses is separate courses on religions and CSR methodology..$^{53}$ Thus, it is expected to be very theoretical. The condition is actually the same as the curriculum in UIN Yogyakarta and Jakarta in the New Order.

However, Amin had started to think that the CSR program should

\footnotetext{
${ }^{53}$ Interview with Nasihun Amin, Semarang February 28, 2014.
} 
not only dwell on the theoretical aspects, but is required to be functional. Gradually, the functionalization of the above theoretical aspects begin to be formulated into "Religion and Conflict Resolution". After going through the deepening and excursion study the Department of CR explicitly creates concentration on "Religion and Peace". ${ }^{54}$

In 2009, the syllabus of CR Department of Semarang was experiencing drastic changes. All courses are directed at achieving the competency of Religion and Peace. In addition to the basic and common subjects in the Faculty of Islamic Theology, they made expertise courses such as Introduction to Peace Studies, Peace Verses Exegesis, the Hadiths of Peace, Theology of Peace, Psychology of Social, Cultural Anthropology, Conflict Theory, Theory of Violence, Human Security, Religious Conflict, Conflict Resolution in Islamic History, Geography of Conflict, Interfaith Dialogue, Peace Education, Peace and Gender, Peace and Development, Religion and Human Rights, Conflict Research Methods, Peace Media, Negotiation, Justice Mediation, Conflict Management Strategies, Non-violence Communications, Conflict Analysis, Culture of Healing, and Peace Initiative Design. Religions course that was made autonomous, now only made one subject only, namely the History of Religions ( 4 credits), which contains the history and basic teachings of the major religions. ${ }^{55}$

If looking at the expertise of the courses, the Wali Songo CSR program does not produce CR scholar who is an expert on religions as common in both UIN Yogyakarta and Jakarta or elsewhere. Output of the concentration on courses above is the emergence of Muslim scholars who are proficient in practice in conflict resolution, accept the offer as a mediator, and mediates conflict to peace for the parties in conflict. In this

\footnotetext{
${ }^{54}$ Interview with Nasihun Amin, Semarang February 28, 2014.

55 See Course syllabus Comparative Religion courses IAIN Semarang Wali Songo, academic year 2009/2010 and 2011 .
} 
context, it is pertinent to say that its shirt is still called 'Comparative Religion' but 'the body' is completely different. With only one course, for example: History of Religions, not likely the 'Comparative Religion' course will give birth scholars whom theoretically mastering Comparative theology of religions. Indeed, IAIN Wali Songo models could have been included in the category of religious studies, not in the sense of the Study of Religions but studying of religions with the approaches of social sciences.

\section{Concluding remarks}

Struggle through its long history, CSR has been transformed in the direction of religious studies as a result of adaptation to the development of religious issues and the development of scientific approaches. Seeing the characteristics change as something that cannot be avoided then the religious studies still have a prospective future. The dynamics of religious life, which is increasingly complex, not simply make religion more loved and studied, but also stimulates the emergence of more and more issues and new approaches in the Study of Religion. Problems such as religious fundamentalism, interfaith-dialogue, the religiousity of disabled people, social inter-religious conflicts, over population, global warming, forest and marine conservation, and a superficial procedural democracy for instances, on the one hand demanding religious studies to bear a perspective that can enlighten the adherents of the religion, and on the other hand are required to develop scientifically a scholarly religious studies. For contemporary issues like those, CR is no longer sufficient. But, for the struggle of theology and spirituality, which would be still ongoing, the CR will remain actual study. Nevertheless, each of these may have a contributory role.

The limitations of this research can be an agenda for further researches. Firstly, considering my research is only done in Jakarta, Yogyakarta and Semarang, it is interesting to examine the CSR in UIN and IAIN else- 
where. For example, this discipline has been developed in both UIN Bandung and Surabaya. It is also very alluring to do comparison research on the development of this field of study in Java and outside of Java (such as the CRS program in Sumatra, Kalimantan and Sulawesi). Secondly, since UIN Yogyakarta, Jakarta and Bandung has opened a Master's program on Religious Studies, it is interesting to conducting research on the development from Comparative Religion to religious studies at post graduate level.

\section{Bibliography}

Abbas, Zainal Arifin. Perkembangan Fikiran Terhadap Agama. Medan: Firma Rahmat \& Pustaka Indonesia, 1965.

Abdurrahman, ed. 70 Tahun H.A.Mukti Ali, Agama dan Masyarakat. Yogyakarta: IAIN Sunan Kalijaga Press, 1993.

Abdurrahman, Moeslim, "Dua Pendekar", in Sukandi (ed.) Tharikat Nurcholishy. Yogyakarta: Pustaka Pelajar, 2001: 60-62.

Ali, Abdullah. Agama Dalam Ilmu Perbandingan. Bandung: Nuansa Aulia, 2007. Ali, Mukti. Bagaimana Menghampiri Isra' Mi'radj Nabi Besar Muhammad SAW atau Iman dan Ilmu Pengetahuan. Jogjakarta: Jajasan Nida, 1969.

Ali, Mukti. Ilmu Perbandingan Agama (Sebuah Pembahasan Tentang Methodos dan Sistima). Yogyakarta: Yayasan Nida, 1969.

Ali, Mukti. Ilmu Perbandingan Agama Di Indonesia. Bandung: Mizan, 1988.

Ali, Mukti. Ke-Esaan Tuhan Dalam Al-Qur'an. Jogyakarta: Jajasan Nida, 1969. Bagir, Zainal Abidin, "Strategi Pengelolaan Program Studi Perbandingan Agama di Indonesia, Tantangan dan Harapan”, Restrukturisasi Program Studi Perbandingan Agama di Indonesia Symposium, Jakarta 26-27 November 2010, UIN Syarif Hidayatullah Jakarta.

Beck, Herman L. "A Pillar of Social Harmony: The Study of Comparative

Religion In Contemporary Indonesia", in Gerard Wiegers (ed.) Modern

Society $\mathcal{E}$ The Science of Religions, Studies In Honour of Lammert Leertouwer. Leiden: Brill, 2002: 231-349.

Boland, B.J. The Struggle of Islam In Indonesia. Leiden: KITLV, 1982.

Daya, Burhanuddin, "Metode Penelitian dan Pengembangan Ilmu Perbandingan

Agama", Metode Penelitian dan Pengembangan Ilmu Pengetahuan Agama Islam Symposium, Yogyakarta 14-16 Maret 1991, Balai Penelitian Pusat Penelitian dan Pengabdian Pada Masyarakat (P3M), IAIN Sunan Kalijaga. Daya, Burhanuddin, "Kuliah Ilmu Perbandingan Agama Pada Institut Agama 
IJIMS, Indonesian Journal of Islam and Muslim Societies, Volume 4, Number 2, December 2014: 155-188

Islam Negeri (IAIN)", in Burhanuddin Daya \& Herman Leonard Beck (eds.) Ilmu Perbandingan Agama di Indonesia dan Belanda. Jakarta: INIS, 1992: 181-197.

Hakim, Agus. Perbandingan Agama, Pandangan Islam Mengenai Kepercayaan Majusi,

Shabiah, Yahudi, Kristen, Hindu, Buddha, Sikh. Semarang: Diponegoro, 2004.

Hidayatullah, Syarif. Studi Agama, Suatu Pengantar. Yogyakarta: Tiara Wacana, 2011.

Ihromi, "Mengkaji Agama-Agama Yang Masih Hidup Dalam Sebuah Masyarakat", in Burhanuddin Daya \& Herman Leonard Beck (eds.) Ilmu Perbandingan Agama di Indonesia dan Belanda. Jakarta: INIS, 1992: 173-179.

Ludjito, "Bapak Ilmu Perbandingan Agama di Indonesia", in Herman Leonard Beck (ed.) Ilmu Perbandingan Agama di Indonesia (Beberapa Permasalahan). Jakarta: INIS, 1990: 13-17.

Munhanif, Ali, "Islam and Struggle for Religious Pluralism in Indonesia; A Political Reading of the Religious Thought of Mukti Ali”, Studia Islamika, Volume 3, Number 1 (1996): 79-126.

Munhanif, Ali, "Prof. Dr. Mukti Ali, Modernisasi Politik-Keagamaan Orde Baru”, in Azyumardi Azra and Saiful Umam (eds.) Menteri-Menteri Agama RI, Biografi Sosial-Politik. Jakarta: INIS, PPIM dan Litbang Agama Depag RI, 1998: 271-319.

Permata, Ahmad Norma (ed.). Metodologi Studi Agama. Yogyakarta: Pustaka Pelajar, 2000.

Rodrigues, Hillary and Harding, John S. Introduction To The Study of Religion. New York: Routledge, 2009.

Ropi, Ismatu. Fragile Relation, Muslims and Christians in Modern Indonesia. Jakarta, Logos, 2000.

Smith, Wilfred Cantwell. "Comparative Religion: Wither-and Why", in Mircea Eliade and Joseph Kitagawa (eds) The History of Religions, Essays in Methodology. Chicago: The University of Chicago Press, 1959: 31-58.

Smith, Wilfred Cantwell. The Meaning and End of Religion. New York: Mentor Books, 1963.

Steenbrink, Karel L, "The Study of Comparative Religion by Indonesian Muslims,” Numen, Volume 37, Fasc. 2 (December 1990): 141-167.

Waardenburg, Jacques. Muslims and Others, Relation in Context. Berlin: Walter de Gruyter, 2003.

Wach, Joachim. The Comparative Study of Religions. New York and London: Columbia University Press, 1958.

Yunus, Mahmud. al-Adyān. Jakarta: Maktabah Sa'diyah Putra, n.y. 